\title{
Adversity Quotient and perception to adversity in differentiating entrepreneurial survival
}

\author{
Izzatul Fathiyah \\ Department of Psychology \\ Faculty of Medicine \\ Hasanuddin University \\ izzatulfthyh@gmail.com
}

\author{
Muhammad Tamar \\ Department of Psychology \\ Faculty of Medicine \\ Hasanuddin University
}

\author{
Triani Arfah \\ Department of Psychology \\ Faculty of Medicine \\ Hasanuddin University
}

\begin{abstract}
As an economic agent, Entrepreneur has a major contribution to the country's economic growth. There are many entrepreneurship programs developed to encourage entrepreneurship, and Student Entrepreneurship Program at Hasanuddin University is one of them. However, there are many challenges and difficulties faced in running a business cause failure during early years. This study aims to examine Adversity Quotient (AQ) and perception of adversity in distinguishing students who continue their business and do not continue their business. This research is a quantitative research with explorative-descriptive research design. There are 66 students consist of 33 students who continue their business and 33 students who do not continue their business participated in this research. The data were obtained by open-ended questions to explore perceptions, adaptations of the Adversity Response Profile scale to measure Adversity Quotient (AQ) and Motivation Scale constructed by investigator based on motivational theory from McClelland (1961). The result of this study shows that there is no difference of perception of students who continue their business and do not continue their business. However, there are differences in AQ and the motivation of students who continue their business and do not continue their business. Adversity Quotient (AQ) in the students who continue the business is in the high category of $52 \%$ and the medium category of $48 \%$. While the students who did not continue the business showed high category $36 \%$, medium category $61 \%$, and low category $3 \%$.
\end{abstract}

Keywords-Adversity Quotient; perception

\section{INTRODUCTION}

Entrepreneur as an economic agent provide a significant contribution to the economic growth of a country. Entrepreneurs are described as individuals who have unique characteristics that are different from others [1]. These characteristics include risk taking, observing opportunities, achievement orientation, creative, innovative, internal locus of control, self-efficacy, and other characteristics related to entrepreneurial attitudes [2] [3].

Global Entrepreneurship Monitor (GEM) reports that in 2013 Indonesian entrepreneurship intention is ranked second in South East Asia [4]. One of the programs that facilitate entrepreneurship intention among students is Student Entrepreneurial Program (PMW). However, being an entrepreneur is not an easy thing. There are many challenges and difficulties encountered in the process of running a business so it is common for many businesses to fail, especially during early years. [5] [6]. Presumably, the reason why students fail to continue their business is due to obstacles faced by being an entrepreneur. Difficulties in the process of achieving goals are Inevitable, including in running a business. However, individual's response to the adversity will differentiate whether the individual will able to survive or surrender to achieve his goal.

In the Student Entrepreneurship Program (PMW), there are students who continue their business longer whilst there are also students who discontinue their business. This present study aims to examine Adversity Quotient (AQ) and perception of adversity in students who registered as a member of Student Entrepreneurial Program (PMW).

\section{LITERATURE REVIEW}

Adversity Quotient (AQ) measure an individual's response in facing difficulties and obstacles. Stoltz [7] proposes instrument to measures the level of human resilience, namely the ability to survive in the face of adversity. Adversity Quotient (AQ) predicts who will survive or who will be broken, who will exceed expectations of performance and potential or who will fail, also predict who will endure or who will give up. Stoltz also argues that a person with high level of resiliency will have more effective and constructive strategy in facing difficulty, and thus will have higher life satisfaction. Adversity Quotient (AQ) consists of four dimensions in measuring individual ability to respond to difficulties. These dimensions are abbreviated as CO2RE which stands for: $\mathrm{C}$ for Control; O2 for Origin and Ownership; R for Reach; E for Endurance [7].

\section{METHOD}

\section{A. Participants}

Population of this study are students registered in Students Entrepreneurship Program (PMW) for the last three years. 
There were 66 students participated in this study selected by purposive sampling with criteria as follows:

- Thirty-three students who still run their business

- Thirty-three students who once actively ran their business but now were inactive.

\section{B. Procedures}

Firstly, participants were recruited based on criteria set. Secondly, participants were give explanation about research. Should they agree to participate, participants were given informed consent to be signed. Last, participants were asked to fill out the questionnaire. Data collection were performed individually.

\section{Measures}

To measure Adversity Quotient (AQ) Adversity Response Profile [7] were translated and adapted to suit participant's background. The instrument was constructed using 5-point scale semantic differential. Prior to data collection, questionnaire was rated using expert judgement. Then readability test of the questionnaire was conducted to 5 students who regarded as representation of participants. The aim was to ensure that language used in questionnaire was understandable to participants. There were no reliability and validity test conducted for this adapted instrument, as it has been conducted repeatedly in the wide range of races, occupations, age group, cultures and the result showed a consistent reliable and valid test [7]

To measure motivation, an instrument was constructed by investigator based on Motivation Theory by McLelland [2]. This instrument was developed to measure three aspects of motivation: need for achievement; need for affiliation; dan need for power.

Prior to instrument test, group of experts were asked to rate the instrument. Then the instrument was given to 5 students to rate the readability of the instrument. The result of these procedures are 64 items which are ready to be tested. Next, the instrument was tested to 100 participants to ensure the validity and reliability of the instrument. There are several items to be deleted after confirmatory factor analysis. The reliability of this instrument using Cronbach Alpha was .832.

In this study, data also collected using open ended questionnaire. This questionnaire was distributed to collect data that might not be covered by AQ instrument. Specifically, open-ended questionnaires were distributed to obtain data regarding students' perception of obstacles for being an entrepreneur

\section{RESULT AND DiSCUSSION}

\section{A. Adversity Quotient}

TABLE I.

ADVERSITY QUOTIENT DISTRIBUTION SCORE

\begin{tabular}{|l|l|l|l|}
\hline \multicolumn{1}{|c|}{ Group of Students } & High & Moderate & Low \\
\hline Continue their business & $52 \%$ & $48 \%$ & - \\
\hline Discontinue their business & $36 \%$ & $61 \%$ & $3 \%$ \\
\hline
\end{tabular}

TABLE II.

ADVERSITY QUOTIENT PROFILE IN STUDENTS WHO CONTINUE THEIR BUSINESS

\begin{tabular}{|l|c|c|c|c|}
\hline \multirow{2}{*}{\multicolumn{1}{|c|}{ Dimension }} & \multicolumn{4}{c|}{ Category (\%) } \\
\cline { 2 - 5 } & High & Moderate & Low & N \\
\hline Control & $18 \%$ & $75 \%$ & $7 \%$ & 33 \\
\hline Origin-Ownership & $45 \%$ & $51 \%$ & $4 \%$ & 33 \\
\hline Reach & $25 \%$ & $75 \%$ & 0 & 33 \\
\hline Endurance & $15 \%$ & $63 \%$ & $22 \%$ & 33 \\
\hline
\end{tabular}

ADVERSITY QUOTIENT PROFILE IN STUDENTS WHO DISCONTINUE THEIR BUSINESS

\begin{tabular}{|l|c|c|c|c|}
\hline \multirow{2}{*}{\multicolumn{1}{|c|}{ Dimension }} & \multicolumn{4}{|c|}{ Category (\%) } \\
\cline { 2 - 5 } & High & Moderate & Low & N \\
\hline Control & $10 \%$ & $73 \%$ & $18 \%$ & 33 \\
\hline Origin-Ownership & $28 \%$ & $73 \%$ & $0 \%$ & 33 \\
\hline Reach & $30 \%$ & $70 \%$ & 0 & 33 \\
\hline Endurance & $15 \%$ & $75 \%$ & $10 \%$ & 33 \\
\hline
\end{tabular}

\section{B. Perception regarding obstacles of entrepreneurial activity} Adversity Quotient

TABLE IV.

PERCEPTION REGARDING ADVERSITY OF STUDENTS WHO CONTINUE THEIR BUSINESS

\begin{tabular}{|l|c|c|}
\hline $\begin{array}{c}\text { Perception regarding } \\
\text { obstacles of entrepreneurial } \\
\text { activity }\end{array}$ & Quantity & Percentage \\
\hline Something can be handled & 9 & $27 \%$ \\
\hline Learning & 5 & $15 \%$ \\
\hline Obstacles, & 5 & $15 \%$ \\
\hline Inevitable & 4 & $12 \%$ \\
\hline Driver & 3 & $9 \%$ \\
\hline Temporary & 1 & $3 \%$ \\
\hline No answer & 5 & $15 \%$ \\
\hline TOTAL & 33 & $100 \%$ \\
\hline
\end{tabular}


TABLE V.

PERCEPTION REGARDING ADVERSITY OF STUDENTS WHO DISCONTINUE THEIR BUSINESS

\begin{tabular}{|l|c|c|}
\hline $\begin{array}{c}\text { Perception regarding } \\
\text { obstacles of entrepreneurial } \\
\text { activity }\end{array}$ & Quantity & Percentage \\
\hline Challenge & 9 & $27 \%$ \\
\hline Something can be handled & 8 & $24 \%$ \\
\hline Obstacles & 5 & $15 \%$ \\
\hline Learning & 4 & $12 \%$ \\
\hline Risk & 2 & $6 \%$ \\
\hline Driver & 1 & $3 \%$ \\
\hline Difficult to overcome & 1 & $3 \%$ \\
\hline Inevitable & 1 & $3 \%$ \\
\hline Others & 1 & $3 \%$ \\
\hline No answer & 1 & $3 \%$ \\
\hline TOTAL & 33 & $100 \%$ \\
\hline
\end{tabular}

Obstacles in entrepreneurial activity is one of the reason why students discontinue their business. Obstacles and difficulties are inevitable including in running a business. How people respond to these obstacles and difficulties will differentiate between people who will survive and people who will fail in achieving their goals. Thus, this study aims to investigate adversity quotient and perception of adversity among students who join Student entrepreneurship program at Hasanuddin University (PMW).

The first set of question aimed to distinguish adversity quotient between students who continue and students who discontinue their business. Generally, students who continue their business have higher adversity quotient than those who discontinue. As can be seen from Table III, there are 52\% of students who continue their business have high adversity quotient compared to only $36 \%$ in students who discontinue their business. Additionally, there are $61 \%$ of students who discontinue their business have moderate level of adversity quotient and the rest $3 \%$ have low adversity quotient.

According to Stoltz, people with high level of adversity quotient are described as people who is ready to succeed and strong enough to overcome adversities and to keep forward despite all obstacles they face. In contrast, campers are described as people who are good enough in taking the twists and turns of life as long as everything goes relatively smooth. However, when faced with many difficulties, campers will experience a burden of unnecessary frustration and suffering and thus are discouraged to show the same fighting spirit as when the condition went smooth.

As can be seen in Table I, most students who continue their business (52\%) are categorized as climbers, who have a strong enough ability to survive in the face of adversity [7]. On the contrary, most students who discontinue their business
(61\%), are included in campers, who have a chance to succeed but still have possibility to give up when faced by difficulties. Campers are more common on subjects who do not continue the business, indicating that the obstacles they face tend to make them to give up.

Theoretically, Adversity Quotient (AQ) is related to individual perception of the obstacles encountered [7]. The result of this study shows generally, students perceptions of obstacles in entrepreneurial activity in students who continue their business and discontinue their business are similar, which perceive obstacles as rather positive as negative. Stoltz [7] suggests that both people with climbers and campers basically perceive obstacles as a challenge or something that can be conquered. However, although campers perceive obstacles as challenges, but when the challenges are difficult to faced, there is a tendency for them to stop and discontinue their struggle. Thus, although both have the same tendency to perceive obstacles, level of Adversity Quotient (AQ) will determine the ability of students to continue the business or discontinue the business.

As can be seen in Table II, participants who continue their business tend to score in origin-ownership dimension and low on endurance dimension. In contrast, as Table III shows that participants who discontinue their business tend to be score high reach die mansion and low on control dimension. Stoltz [7] states that individuals with high origin and ownership scores have ability to place their responsibilities in the right places and avoid excessive self-blame behavior. Individuals with high reach dimension scores respond to adversity as something specific and limited and thus do not let the problem spread to other aspects of their life. The low scores on the endurance dimension indicate that individuals tend to regard a difficulty as permanent. While individuals who are low on the dimensions of control indicate that individuals tend to regard difficulty as something that is difficult to control.

To conclude, participants who continue their business tend to have personal responsibility and ability to place guilt with a reasonable degree but at the same time shows the tendency to perceive a difficulty as permanent. In contrast, participants who discontinue their business tend to consider difficulty as something that is limited to a part of life and does not extend to other aspects of life, but at the same time show tendency to assume that bad events are something that cannot be controlled. However, cautious interpretation must be implemented. In this study, data collection was performed individually rather than classical. Consequently, there might be different treatment form investigator for each participant. The difference of time, place, situation, and instruction might interfere participant's internal process and thus might influence participant response to questionnaire.

\section{CONCLUSION}

This study set out to gain a better understanding in how adversity quotient and perception of adversity distinguish entrepreneurial survival. Entrepreneurs provide significant 
contribution to economic growth of a country, and thus entrepreneurial activity must be encouraged. The result of this study shows that students who continue and discontinue their business have similar perception to adversity. Most of them perceive adversity positive: a challenge to be concurred. However, their level of adversity quotient is what differentiate between these two groups. Group of students who continue their business have a higher adversity quotient than group of students who discontinue their business. Most of students who continue their business are climbers (52\%). In contrast, students who discontinue their business are mostly campers. To conclude, is not how students perceive adversities, is how resilience are they in the face of adversity that differentiate their entrepreneurial survival.

\section{REFERENCES}

[1] R.A. Baron, D. Byrne, and N.R. Branscombe. Social Psychology: Eleventh Edition. USA: Pearson, 2006

[2] D.C. McClelland. The Achieving Society. USA: Van Nostrand Company, 1961
[3] J.A.M. Leon, and M. Gorgievski. Psychology of Entrepreneurship: Research and Education. Madrid: Universidad Nacional de Educación a Distancia, 2007

[4] DetikFinance. " Perbanyak jumlah pengusaha, ini yang dilakukan pemerintah".https://finance.detik.com/berita-ekonomibisnis/2854282/perbanyak-jumlah-pengusaha-ini-yang-dilakukanpemerintah Mar. 10, 2015, [Jul. 25, 2017]

[5] R.E. Halim, A. Aziz, and Firmanzah. (2014). "Faktor Kunci Sukses Perusahaan Kecil dan Menengah dalam Menghindari Kegagalan pada Periode Lima Tahun Pertama". Jurnal Ekonomi, Vol. 9, pp. 71-84, 2014

[6] D. Wisesa, and K.R. Indrawati, K. R. "Hubungan Adversity Quotient $(A Q)$ dengan Motivasi Berwirausaha pada Mahasiswa Universitas Udayana yang Mengikuti Program Mahasiswa Wirausaha." Jurnal Psikologi Udayana, Vol. 3, pp.187-195, 2016

[7] P.G. Stoltz, Adversity Quotient: Mengubah Hambatan Menjadi Peluang. Jakarta: Grasindo, 200 